\title{
OPTIMALISASI UJI TINGKAT KOMPETENSI DI SMK UNTUK MENINGKATKAN SOFT SKILL LULUSAN
}

\author{
Badrun Kartowagiran \\ Jurusan Pendidikan Teknik Mesin Fakultas Teknik Universitas Negeri Yogyakarta \\ Email: kartowagiran@uny.ac.id
}

\begin{abstract}
Competency level test (UTK) is a specific level competency test conducted by an education unit using a Government standard table of specifications. This is an extra task for the education unit, adding load to an already fully-load unit. Without special attention, it is possible that UTK is merely just a label, and just for routine. For vocational high schools, UTK is carried out through the National Examination which is also the final level of competency test. UTK optimization is an all-out effort to make the UTK instruments and its implementation have high quality standards. This will ensure that the graduates' qualifications meet the standards and the students also have required soft skills. Efforts in producing high quality UTK test questions are done by tightening of content validity, predictive validity, and the reliability of UTK test questions. The method is called the ICC interrater and Cohen Kappa. The optimization of UTK is able to improve soft skills because the students are encouraged to meet the competency standards of hard work, tenacity, earnest, hard work, responsibility and punctuality.
\end{abstract}

Keywords: optimization of utk, competency, 2013 curriculum

\begin{abstract}
ABSTRAK
Uji tingkat kompetensi merupakan uji kompetensi pada tingkat tertentu yang dilakukan oleh satuan pendidikan dengan menggunakan kisi-kisi yang disusun oleh Pemerintah. Kegiatan ini menambah tugas bagi satuan pendidikan, sehingga beban sekolah terlalu besar. Apabila tidak ada perhatian khusus, tidak menutup kemungkinan UTK hanya sekedar label, bahkan asal jalan. Untuk SMK, UTK dilakukan melalui UN yang berarti juga merupakan uji kompetensi akhir jenjang. Optimalisasi UTK adalah usaha keras agar instrumen dan pelaksanaan UTK berkualitas tinggi sehingga kualifikasi lulusannya kompetensi pengetahuan dan keterampilan sesuai standar yang telah ditentukan dan memiliki soft skill. Upaya untuk menghasilkan soal UTK yang berkualitas tinggi dilakukan dengan cara memperketat validitas isi, validitas prediktif, dan memperketat reliabilitas soal UTK. Metode yang digunakan yaitu interrater ICC dan Cohen Kappa. Optimalisasi TUK mampu meningkatkan softskill karena siswa didorong lulus sesuai standar kompetensi sehingga siswa didorong lebih ulet, sungguh-sungguh, kerja keras, tanggung jawab dan menghargai waktu.
\end{abstract}

Kata Kunci: Optimalisasi UTK, Kompetensi siswa, Kurikulum 2013

\section{PENDAHULUAN}

Bahrul Hayat, Ketua Himpunan Evaluasi Pendidikan Indonesia (HEPI), mengatakan bahwa kurikulum 2013 ini memiliki dua kelemahan, yaitu: kelemahan pada aspek idealistik dan kelemahan pada aspek praksis. Pada aspek idealistik, kurikulum tahun 2013 selalu memuat materi hari ini ke belakang; tidak ada mata pelajaran hari ini ke depan. Oleh karena itu, kita selalu tertinggal dalam menyusun kurikulum. Lebih jauh Bahrul Hayat menjelaskan, kelemahan aspek praksis adalah cara melakukan penilaian atau asesmen. Dengan pendekatan tematik integratif, seorang guru bisa mengajarkan banyak hal dalam satu waktu, tetapi sewaktu menilai, guru harus spesifik substansi yang dinilai.

Keraguan Bahrul Hayat ini dapat difahami karena lapangan menunjukkan bahwa sebagian besar sekolah belum siap mengimplementasikan kurikulum tahun 2013 ini. Penelitian Badrun Kartowagiran (2013) terhadap 15 SMP di Daerah Istimewa Yogyakarta (DIY) menunjukkan bahwa 
sebagian besar (82\%) belum siap mengimplementasikan kurikulum tahun 2013.

Ungkapan Bahrul Hayat dan hasil penelitian Badrun Kartowagiran di atas harus ditanggapi secara positif. Pemerintah dan masyarakat harus sadar bahwa untuk dapat mengimplementasikan kurikulum tahun 2013, termasuk melakukan penilaian dengan baik masih diperlukan kerja keras. Masih diperlukan upaya-upaya tambahan agar implementasi kurikulum tahun 2013 berjalan lancar. Sementara itu, satuan pendidikan juga harus menyelenggarakan ujian sekolah dan uji tingkat kompetensi (UTK) dengan menggunakan kisikisi yang disusun oleh Pemerintah. UTK dilakukan oleh satuan pendidikan pada akhir kelas II (tingkat 1), kelas IV (tingkat 2), kelas VIII (tingkat 4), dan kelas XI (tingkat 5), Ujian tingkat kompetensi pada akhir kelas VI (tingkat 3), kelas IX (tingkat 4A), dan kelas XII (tingkat 6). UTK pada akhir kelas VI (tingkat 3), kelas IX (tingkat 4A) dan kelas XII (tingkat 6) dilakukan melalui UN (Permendikbud R.I. nomor 66 Tahun 2013 tentang Standar Penilaian).

Uraian di atas memberi gambaran bahwa tugas satuan pendidikan saat ini sangat padat karena harus menyelenggarakan ujian sekolah dan uji tingkat kompetensi (UTK). Apabila tidak ada perhatian khusus, tidak menutup kemungkinan UTK hanya sekedar label, bahkan asal jalan. UTK dilaksanakan sekadarnya dan akhirnya hasil tidak dapat dimanfaatkan secara maksimal. Oleh karenanya optimalisasi UTK perlu dilakukan.

Optimalisasi UTK adalah usaha memaksimumkan hasil UTK dan pemanfaatannya. Jangan sampai hasil UTK tidak tepat sehingga tidak dapat dimanfaatkan. Atau, hasil UTK tepat namun karena tidak kontekstual maka hasilnya tidak dapat dimanfaatkan secara optimal. Agar hasil UTK tepat maka ada dua hal yang harus diusahakan, yakni: kualitas soal yang digunakan dan kualitas pelaksanaan UTK harus tinggi. Ini berarti bahwa optimalisasi UTK dapat tercapai manakala instrumen dan pelaksanaan UTK berkualitas tinggi sehingga kualifikasi lulusannya sesuai dengan kebutuhan bangsa di masa datang, khususnya Indonesia Emas. Lulusannya memiliki kompetensi pengetahuan dan keterampilan sesuai standar dan memiliki soft skill.

Kualitas Instrumen (soal UTK). Syarat instrumen yang baik adalah instrumen yang memiliki validitas dan reliabilitas tinggi atau memenuhi persyaratan psikometrik. Menurut pendekatan teori tes klasik, validitas suatu alat ukur adalah sejauhmana alat ukur itu mampu mengukur apa yang seharusnya diukur (Nunnally, 1978). Sejauhmana besaran skor tampak (X) mendekati besaran skor murni (T), semakin jauh perbedaan antara skor tampak dan skor murni berarti semakin kecil validitas alat ukur tersebut.

Instrumen yang baik juga harus memiliki reliabilitas tinggi, yakni memiliki keajegan atau kestabilan hasil pengukuran. Alat ukur yang reliabel adalah alat ukur yang mampu membuahkan hasil pengukuran yang stabil (Lawrence, 1994). Dalam ilmu sosial hal ini sulit sekali terjadi karena banyak faktor yang mempengaruhinya. Jika dilakukan pengukuran pada kelompok yang sama dua kali secara berurutan, beberapa variasi skor dapat terjadi karena adanya fluktuasi pada memori sesaat, perhatian, kelelahan, ketegangan emosional, tebak-tebak dan sejenisnya. Sebaliknya jika dilaksanakan dalam waktu yang lama antara tes pertama dan tes kedua variasi skor kemungkinan disebabkan oleh pengaruh pengalaman belajar, perubahan kesehatan, lupa dan lainlain. Variasi skor juga mungkin terjadi jika hasil tes uraian dikoreksi oleh orang yang berbeda atau pengukuran kinerja siswa dilakukan oleh orang yang berbeda. Variasi skor juga akan terjadi jika digunakan sampel tugas yang berbeda dari domain yang sama. Adanya variasi hasil pengukuran ini menunjukkan adanya kesalahan pengukuran.

Hal senada disampaikan Nunnally (1978) yang mengatakan bahwa banyak faktor yang mempengaruhi ketepatan pengukuran. Jenis dan jumlah penyebab kesalahan ini 
tergantung pada karakteristik tes dan bagaimana tes itu digunakan. Hal penting yang perlu diperhatikan adalah harus dibedakan antara kesalahan pengukuran yang menyebabkan variasi penampilan dari butir-kebutir dalam suatu tes dan kesalahan yang dimanifestasikan dalam variasi penampilan dalam bentuk tes berbeda diberikan pada waktu sama atau berbeda waktunya. Kesalahan tipe pertama dikarenakan sampling butir. Semakin banyak butir yang diambil semakin berkurang kesalahannya, asalkan korelasi antara butir yang satu dengan lainnya tinggi atau korelasi antara skor butir dengan skor keseluruhan itu tinggi. Kesalahan tipe kedua dikarenakan tingkat paralelisme dua tes yang digunakan, semakin tinggi kualitas indikator semakin kecil kemungkinannya kesalahan tipe kedua muncul.

Para ahli (Nunnally, 1978, Allen \& Yen, 1979, Fernandes, 1984, Woolfolk \& McCane, 1984, dan Lawrence, 1994), menjelaskan bahwa validitas dapat dikelompokkan menjadi tiga tipe, yaitu: (1) validitas kriteria, (2) validitas isi, dan (3) validitas konstruk. Validitas kriteria dibedakan menjadi dua, yaitu validitas prediktif dan validitas konkuren. Fernandes (1984) mengatakan validitas berdasarkan kriteria dimaksudkan untuk menjawab pertanyaan: "How well test performance predicts future performance (predictive validity) or estimate current performance on some valued measure other than the test itself (concurrent validity)?”. Senada hal ini, Nunnally (1978) berpendapat validitas prediktif diestimasi manakala instrumen dimaksudkan sebagai prediktor bagi performansi di waktu yang akan datang. Sementara itu instrumen dikatakan memiliki validitas konkuren tinggi bila skor hasil pengukuran dengan instrumen yang dikembangkn berkorelasi tinggi dengan skor hasil pengukuran menggunakan instrumen yang sudah valid. Dalam analisis validitas prediktif dan konkuren, performansi yang hendak diprediksikan disebut dengan kriteria. Besar kecilnya harga estimasi validitas prediktif atau konkuren suatu instrumen digambarkan dengan keofisien korelasi antara prediktor dengan kriteria tersebut.

Validitas isi suatu instrumen adalah sejauhmana butir-butir dalam instrumen itu mewakili komponen-komponen dalam keseluruhan kawasan isi objek yang hendak diukur (aspek representasi) dan sejauh mana butir-butir itu mencerminkan ciri perilaku yang hendak diukur (aspek relevansi) (Fernandes, 1984; Nunnally, 1978). Validitas konstruk adalah validitas yang menunjukkan sejauhmana instrumen mengungkap suatu trait atau konstruk teoritik yang hendak diukurnya (Saifuddin Azwar, 2013; Allen \& Yen, 1979; Nunnally, 1978). Pengujian validitas konstruk merupakan proses yang terus berlanjut sejalan dengan perkembangan konsep trait yang akan diukur. Perubahan dan perkembangan konsep seperti ini merupakan hal biasa dalam bidang psikologi karena variabel itu pada dasarnya merupakan konsep hipotetik yang tidak selalu mudah untuk dioperasionalkan.

Konsep validitas konstruk sangat bermanfaat pada tes yang mengukur trait yang tidak memiliki kriteria eksternal. Untuk itu prosedur validasi konstruk diawali dari suatu identifikasi dan batasan mengenai variabel yang hendak diukur dan dinyatakan dalam bentuk konstruk logis berdasarkan teori mengenai variabel tersebut. Dari teori ini ditarik suatu konskuensi praktis mengenai hasil pengukuran pada kondisi tertentu, dan konskuensi inilah yang akan diuji. Apabila hasilnya sesuai dengan harapan maka instrumen itu dianggap memiliki validitas konstruk yang baik.

Uji Tingkat Kompetensi (UTK) merupakan uji kompetensi pada tingkat tertentu, oleh karenanya kualifikasi lulusan UTK harus dikaitkan dengan Kerangka Kualifikasi Nasional Indonesia (KKNI). Menurut Pasal 5 Perpres R.I. Nomor 8 Tahun 2012 Tentang Kerangka Kualifikasi Nasional Indonesia, lulusan pendidikan menengah paling rendah setara dengan jenjang 2. Selanjutnya dalam Perpres itu dijelaskan bahwa lulusan yang memiliki kemampuan setingkat jenjang 2 itu harus memiliki kemampuan dan tanggung 
jawab sebagai berikut: (1) mampu melaksanakan satu tugas spesifik, dengan menggunakan alat, dan informasi, dan prosedur kerja yang lazim dilakukan, serta menunjukkan kinerja dengan mutu yang terukur, di bawah pengawasan langsung atasannya; (2) memiliki pengetahuan operasional dasar dan pengetahuan faktual bidang kerja yang spesifik, sehingga mampu memilih penyelesaian yang tersedia terhadap masalah yang lazim timbul; dan (3) bertanggung jawab pada pekerjaan sendiri dan dapat diberi tanggung jawab membimbing orang lain.

KKNI jenjang 2 seperti yang dijelaskan di atas merupakan Standar Kompetensi Lulusan (SKL) bagi lulusan SMK beberapa tahun mendatang. Selanjutnya SKL ini digunakan sebagai acuan dalam mengembangkan standar isi, standar proses, dan standar penilaian. Ini berarti bahwa cakupan materi yg diujikan dalam UTK adalah materi yang harus diberikan agar tujuan UTK yang setara dengan KKNI jenjang 2 ini dicapai. Proses pembelajaran yang harus dilakukan di SMK adalah kegiatankegiatan untuk mempelajari pengetahuan, dan atau berlatih keterampilan, dan atau berlatih mengamalkan sikap spiritual dan sikap sosial sedemikian rupa agar SKL tercapai. Penilaian kompetensi lulusan atau UTK harus menggunakan berbagai teknik penilaian sehingga mampu mengungkap kompetensi pengetahuan, kompetensi keterampilan, dan kompetensi sikap dari peserta UTK.

Uji tingkat kompetensi (UTK) termasuk tes prestasi belajar, maka teknik validasi yang paling tepat adalah validitas isi. UTK memiliki validitas isi manakala materi yang diujikan mewakili komponen-komponen yang ada dalam KKNI jenjang 2. UTK harus mencakup uji pengetahuan atau Teori Kejuruan dan Praktik Kejuruan. Butir-butir UTK juga harus mampu mendorong munculnya perilaku yang ada dalam KKNI jenjang 2, misal cermat, tanggung jawab, dan jujur.

\section{METODE}

Cara memastikan apakah UTK memiliki validitas isi atau tidak dapat dilakukan dua langkah, yakni mencermati validitas tampang dan mencermati validitas logis. Sesuai dengan namanya, validitas tampang adalah validitas instrumen yang didasarkan pada penilaian pakar terhadap tes itu. Menurut pakar apakah format tes itu sudah layak dan butir-butir dalam instrumen itu sudah mengukur apa yang seharusnya diukur. Bila ya, maka dikatakan bahwa tes itu memiliki validitas tampang yang baik.

Setelah tes itu memenuhi validitas tampang, selanjutnya tes itu dicek validitas logiknya. Pada dasarnya, validitas logik adalah sejauhmana butir-butir tes itu representatif mewakili semua materi, pengetahuan, keterampilan, dan perilaku yang akan diukur. Agar mudah memilih butir yang mewakili atribut yang akan diukur, tes harus dirancang secermat mungkin. Rancangan ini dapat berupa tabel spesifikasi yang berisi tujuan tes dan kisikisi tes. Kisi-kisi merupakan panduan penulisan bahan ajar, dan panduan penyusunan butir-butir soal. Kisi-kisi memuat kompetensi inti, kompetensi dasar, dan indikator pencapaian. Butir-butir soal ditulis mengacu pada indikator pencapaian.

Cara memantapkan kecermatan validitas isi, butir-butir soal tadi dinilai ketepatannya oleh lebih dari satu pakar penilai (panel). Para penilai ini memberikan penilaian terhadap setiap butir tes, yakni sejauhmana butir-butir tes itu representatif mewakili materi pengetahuan, keterampilan, dan perilaku yang akan diukur. Penilaian dilakukan dengan cara memberikan skor 1 (sangat tidak mewakili atau sangat tidak relevan) sampai dengan 5 (sangat mewakili atau sangat relevan). Selanjutnya digunakan persamaan V dari Aikens (Saifuddin Azwar, 2013):

$$
\begin{aligned}
& \mathrm{V}=\sum \mathrm{s} /[\mathrm{n}(\mathrm{c}-1)] \\
& \mathrm{S}=\mathrm{r}-\mathrm{lo} \\
& \begin{array}{l}
\sum \mathrm{s}=\mathrm{s} 1+\mathrm{s} 2+\mathrm{dst} \\
\mathrm{Lo} \quad=\text { angka penilaian validitas yang } \\
\quad \text { terendah }
\end{array}
\end{aligned}
$$




$$
\begin{aligned}
& \mathrm{c}=\text { angka penilaian validitas yang tertinggi } \\
& \mathrm{r}=\text { angka yang diberikan oleh seorang } \\
& \text { penilai }
\end{aligned}
$$

Selain menggunakan persamaan Aiken, validitas isi juga dapat diestimasi menggunakan rumus Lawshe, yakni content validity ratio (CVR) diteruskan dengan ke Content Validity Index (CVI). CVR adalah validitas isi dari suatu butir menurut penilaian para ahli yang disebut dengan Subject Matter Experts (SME). Penilaian SME terhadap suatu butir bergradasi, yakni: esensial, berguna tetapi tidak esensial, dan tidak diperlukan. Suatu butir dianggap memiliki validitas isi tinggi manakala butir itu esensial bagi operasionalisasi konstruk teoritik tes yang disusun. Rumus CVR yang dimaksudkan adalah sebagai berikut (Saifuddin Azwar, 2013).

$$
\begin{aligned}
& \text { CVR }=[(2 \mathrm{ne} / \mathrm{n})-1] \\
& \mathrm{ne}= \text { banyaknya SME yang menilai suatu } \\
& \text { butir tes itu esensial } \\
& \mathrm{n}= \text { banyaknya SME yang melakukan } \\
& \text { penilaian }
\end{aligned}
$$

Sebagai contoh, suatu butir dinilai tingkat esensialnya oleh 10 penilai (SME); enam penilai menyatakan bahwa butir itu esensial, tiga penilai menyatakan butir itu berguna tetapi tidak esensial, dan 1 penilai menyatakan bahwa butir itu tidak diperlukan. Dengan demikian CVR $=[(2.6) / 10-1]=0,20$

Angka CVR bergerak dari -1,00 sampai dengan $+1,00$ bila harga CVR positif atau $>0$ maka 50\% SME menilai butir itu esensial. Semakin tinggi harga CVR, semakin baik validitas isi butir itu. Dalam hal ini butir dikatakan memiliki validitas baik bila CVR $\geq$ 0,3 . Sementara itu validitas isi suatu tes atau Content Validity Index (CVI) adalah rata-rata dari CVR semua butir, sehingga $\mathrm{CVI}=$ ( $\left.\sum \mathrm{CVR}\right) / \mathrm{k} ; \mathrm{k}=$ jumlah butir dalam tes. Dalam hal ini, tidak semua butir dapat dimasukkan dalam rumus CVI, namun hanya butir-butir tepilih atau butir yang memiliki harga CVR $\geq$
0,3. Hal ini dapat difahami karena sebaiknya tes itu terdiri dari butir-butir yang baik.

Selain memiliki validitas, butir-butir soal UTK juga harus memiliki karakteristik, misal tingkat kesulitan dan daya beda yang baik. Karakteristik butir-butir soal UTK dapat dihitung menurut pendekatan teori tes klasik dan/atau teori respon butir. Tulisan ini hanya membatasi pada pendekatan teori tes klasik, karena pendekatan ini yang lebih murah dan lebih mudah dilaksanakan.

\section{HASIL DAN PEMBAHASAN}

Pendekatan teori tes klasik karakteristik butir meliputi tingkat kesukaran (p), daya pembeda (d), dan efektivitas distraktor. Selain itu, dengan analisis kuantitatif pendekatan teori klasik juga dapat diketahui reliabilitas soal tes, dan kesalahan baku pengukuran. Untuk melihat tingkat kesukaran, daya pembeda, dan efektivitas distraktor dilakukan analisis setiap butir tes, sedangkan reliabilitas dan kesalahan pengukuran baku dapat dilihat dengan cara menganalisis soal tes secara keseluruhan. Tingkat kesukaran (p) dapat diperoleh dengan beberapa cara, antara lain: (1) skala kesukaran linier; (2) skala bivariat; (3) indeks Davis; dan (4) proporsi menjawab benar. Cara yang paling mudah dan paling banyak digunakan adalah skala rata-rata atau proporsi menjawab benar atau proportion correct (p), yaitu jumlah peserta tes yang menjawab benar pada butir yang dianalisis dibandingkan dengan peserta tes seluruhnya.

Tingkat kesukaran (p) mengandung banyak kelemahan, antara lain tingkat kesukaran sebenarnya merupakan ukuran kemudahan butir karena semakin tinggi indeks $p$, semakin mudah butir tersebut. Sebaliknya semakin rendah $p$ semakin sulit. Oleh karenanya ada beberapa ahli pengukuran yang menyebut tingkat kesukaran ini dengan tingkat kemudahan. Tingkat kesukaran merupakan salah satu parameter butir soal, yang disimbolkan $\left(P_{i}\right)$, yakni rasio antara jawaban benar dan banyaknya penjawab butir soal. 
Besarnya tingkat kesukaran berkisar antara nol dan satu. Suatu butir kadang-kadang dikategorikan ke dalam ekstrim sukar yaitu apabila nilai p mendekati nol dan ekstrim mudah apabila nilai p mendekati satu. Menurut Fernandes (1984), butir soal yang menghasilkan rerata skor sekitar $50 \%$ dari skor maksimum dapat dikatakan bahwa butir soal itu mempunyai tingkat kesukaran yang tepat. Sementara itu, Thomas dan Dawson (1972) menjelaskan bahwa butir soal yang memiliki tingkat kesukaran 0,25 - 0,75 sudah dikatakan baik.

Daya pembeda atau daya beda suatu butir tes berfungsi untuk menentukan dapat tidaknya suatu butir tes membedakan kelompok dalam aspek yang diukur sesuai dengan perbedaan yang ada pada kelompok itu. Tujuan dari penelaahan daya pembeda adalah untuk melihat kemampuan butir tes tertentu dalam membedakan antara pengambil tes yang berkemampuan tinggi dan pengambil tes yang berkemampuan rendah.

Ada beberapa cara yang digunakan untuk menghitung daya pembeda, yaitu: (1) indeks diskriminasi, (2) indeks korelasi, dan (3) indeks keselarasan. Pada tulisan ini hanya dibahas dua cara untuk menghitung daya pembeda dengan metode korelasi, yaitu korelasi point biserial dan korelasi biserial. Korelasi point biserial maupun korelasi biserial adalah korelasi product moment yang diterapkan pada data, variabel-variabel yang dikorelasikan sifatnya masing-masing berbeda satu sama lain. Korelasi point biserial adalah korelasi dua variabel, satu variabel berskala nominal atau dikotomi yaitu bernilai 1 untuk jawaban benar dan 0 untuk jawaban salah, sedangkan variabel lainnya berskala interval atau rasio. Korelasi biserial adalah korelasi dua variabel, satu variabel berskala ordinal, sedangkan variabel lainnya berskala interval atau rasio.

Indeks daya beda butir soal dapat digunakan sebagai bahan pertimbangan sebuah butir baik atau tidak baik. Butir soal yang baik adalah butir soal yang mempunyai indeks daya beda lebih dari 0,2 (Fernandes, 1984).
Sementara Ebel (1972) menjelaskan suatu butir soal dikatakan berkualitas apabila indeks diskriminasi atau daya pembedanya paling sedikit 0,41 .

Hal penting yang juga harus diperhatikan dalam menganalisis empirik butir soal adalah kemampuan distraktor atau alternatif jawaban yang disediakan menarik peserta tes untuk memilihnya. Jangan sampai tidak seorang peserta tes-pun memilih alternatif jawaban yang disediakan. Fernandes (1984) yang mengutip pendapat Brawn menjelaskan distraktor dikatakan baik apabila paling tidak dipilih oleh $2 \%$ dari seluruh peserta. Sementara itu, Nitko (1996) mengatakan distraktor dikatakan berfungsi manakala paling tidak dipilih oleh seorang peserta tes dari kelompok rendah. Pemilih dari kelompok rendah harus lebih banyak daripada kelompok atas. Distraktor juga dapat dikatakan berfungsi manakala peserta tes (siswa) dari kelompok atas dapat membedakan antara distraktor dan kunci jawaban sehingga yang memilih kunci jawaban lebih banyak daripada yang memilih distraktor.

Proses menganalisis distribusi jawaban juga perlu memperhatikan kemungkinan salah kunci, yaitu manakala siswa dari kelompok atas yang memilih pengecoh lebih banyak daripada yang memilih kunci jawaban. Selain itu, juga perlu dideteksi ada tidaknya unsur tebakan dalam memilih alternatif jawaban. Hal ini dapat dilihat apabila jawaban peserta tes (siswa) merata, baik jawaban dari siswa kelompok atas maupun kelompok bawah.

Hal penting lainnya dalam menuliskan butir-butir soal UTK adalah sebagian besar butir-butir soal itu sebaiknya memenuhi the higher level of thinking (HOT). Menurut Moore, B dan Stanley T (2010), dari peringkat kognitif Bloom itu, urutan nomor 1 - 3, yakni pengetahuan, pemahaman, dan aplikasi dikategorikan the lower level of thinking. Sementara itu tingkat 4 -6, yakni analisis, evaluasi, dan kreasi termasuk the higher level of thinking (HOT). Ini berarti bahwa sebagian besar butir-butir soal UTK sebaiknya berada pada tingkat analisis, evaluasi, dan kreasi. 
Dengan demikian jelaslah bahwa untuk menilai kualitas butir tes dengan pendekatan teori tes klasik tidak cukup hanya memperhatikan tingkat kesukaran dan daya pembeda butir tes yang bersangkutan. Penilaian kualitas butir tes juga harus memperhatikan tingkat kognitif Bloom butir itu dan juga keberfungsian pilihan jawaban, terutama distraktor-distraktornya. Pilihan jawaban itu harus tampak sebagai jawaban yang benar bagi subjek dari kelompok yang berkemampuan rendah. Sebaliknya harus tampak sebagai jawaban yang salah bagi subjek dari kelompok yang berkemampuan tinggi.

Telah dijelaskan bahwa selain valid, soal UTK juga harus reliabel, andal, stabil, atau konsisten. Bila instrumen menggunakan metode rating atau pemberian skor berdasarkan judgment subyektif terhadap atribut tertentu yang dilakukan melalui pengamatan sistematis secara langsung maupun tidak langsung, maka reliabilitasnya dapat dihitung menggunakan persamaan Ebel (Saifuddin Azwar, 2013). Estimasi reliabilitas dapat dilakukan dengan cara memberi angka ulang pada atribut yang sama pada waktu berbeda kemudian mengkorelasikan kedua hasil rating itu. Biasanya teknik korelasi yang digunakan adalah koefisien korelasi jenjang Spearman (rankorder correlation). Teknik ini banyak kelemahan karena besarnya varians error dikarenakan adanya pengaruh faktor ingatan (memory) dari fihak rater.

Cara yang lebih praktis adalah memperbanyak rater, rater lebih dari satu tetapi setara kepakarannya dan independen satu sama lain. Bila rating dilakukan oleh beberapa raters maka makna reliabilitas hasil rating merupakan konsistensi diantara para raters (interrater reliability) atau ada juga yang menyebut dengan Intraclass Correlation Coefficients (ICC).

Penggunaan langkah-langkah yang telah dijelaskan di atas akan diperoleh soal UTK yang berkualitas tinggi. Untuk mendapatkan hasil yang akurat, selain soal tes yang baik pelaksanaan tes juga harus baik. Oleh karenanya, harus diupayakan sekuat tenaga agar pelaksanaan UTK di SMK yang berarti juga pelaksanaan UN berkualitas tinggi. Pelaksanaan UTK yang baik, harus jujur dan tidak akan meluluskan siswa yang belum memenuhi persyaratan. Pelaksanaan UN yang baik juga harus adil, dan dapat dipertanggungjawabkan. Dalam pelaksanan UTK yang baik, siswa yang dapat lulus adalah siswa yang betul-betul memenuhi persyaratan akademik dan nonakademik (berperilaku baik). Hal ini akan mendorong siswa untuk belajar lebih sungguhsungguh, lebih ulet, bekerja lebih keras, lebih menghargai waktu, lebih tanggung jawab, dan lebih religius karena lebih banyak berdoa. Hal ini selaras dengan pendapat Khairil Anwar Notodipuro (2012) yang mengatakan bahwa UN yang diselenggarakan dengan baik akan mendorong siswa lebih tanggung jawab, ulet, lebih menghargai waktu, dan lebih religius.

Hasil penelitian Djemari Mardapi dan Badrun Kartowagiran (2010) menunjukkan bahwa dengan adanya UN maka ada $81 \%$ siswa dari sekolah kategori tinggi dan 65\% siswa dari sekolah kategori rendah menambah jam belajar sekitar $10 \mathrm{jam} /$ minggu dengan cara mengikuti les di sekolah. Sementara itu, Khairil Anwar Notodipuro (2012) yang mengutip hasil penelitian Djemari Mardapi, penelitian Supriyoko, dan penelitian Furqon mengatakan bahwa UN dapat mendorong siswa untuk lebih semangat belajar, rajin mencari sumber bacaan, dan rajin masuk sekolah.

Uraian di atas menjelaskan bahwa dengan mengoptimalkan UTK di SMK yang berarti mengoptimalkan UN maka akan mendorong siswa untuk bekerja lebih keras, belajar lebih sungguh-sungguh, lebih menghargai waktu, lebih ulet, dan lebih tanggung jawab. Butir-butir perilaku positif ini merupakan bagian dari butir-butir soft skill. Hal ini sejalan dengan pendapat Perreault (Mitchel, 2008) yang menjelaskan bahwa soft skills merupakan kualitas personal, atribut atau tingkat komitmen seseorang, yang membedakan orang tersebut dengan orang lain yang memiliki kecerdasan dan pengalaman sama. Sementara 
itu, Mitchel (2008) yang mengutip pendapat James dan James mengatakan bahwa soft skills merupakan cara baru untuk mendeskripsikan seperangkat kemampuan atau talenta seseorang yang tampak saat dia bekerja. Lebih jauh James dan James menjelaskan bahwa soft skills seperti kemampuan untuk bekerja dalam tim, keterampilan berkomunikasi, keterampilan kepemimpinan, layanan langganan, dan keterampilan pemecahan masalah sangat bermanfaat untuk perkembangan karir.

\section{SIMPULAN}

Kualitas soal UTK yang tinggi akan membuahkan hasil UTK yang akurat, sehingga siswa yang dinyatakan lulus betul-betul memiliki kompetensi tinggi atau sesuai dengan standar yang telah ditentukan. Lain halnya bila soal UTK berkualitas rendah maka siswa yang dinyatakan lulus belum tentu mereka memiliki kompetensi tinggi atau sesuai standar yang telah ditentukan. Pelaksanaan UTK yang baik, yakni jujur, disiplin, dan akuntabel hanya meluluskan siswa yang betul-betul sudah memenuhi standar. Hal ini mendorong siswa untuk lebih ulet, bekerja lebih keras, belajar lebih sungguh-sungguh, lebih menghargai waktu, dan lebih tanggung jawab. Uraian di atas dapat disimpulkan bahwa dengan optimalisasi UTK, yakni mengusahakan agar soal dan pelaksanaan UTK berkualitas tinggi, dapat mendorong lulusan berkualitas tinggi dan meningkatkan soft skill lulusannya.

\section{DAFTAR RUJUKAN}

Allen, M.J. \& Yen, W.M. 1979. Introduction to measurement theory. Monterey, CA: Brooks/Cole Publishing Company.

Badrun Kartowagiran, Amat Jaedun, dan Heri Retnowati. Evaluasi kesiapan SMP di D.I. Yogyakarta dalam mengimplementasikan kurikulum tahun 2013. Laporan Penelitian. Yogyakarta: tidak diterbitkan.
Djemari Mardapi dan Badrun Kartowagiran. 2010. Dampak Ujian Nasional. Laporan Penelitian. Yogyakarta: tidak diterbitkan

Dawson, J.B. \& Thomas, G.H. 1972. Item analysis and examination statics. Birmingham: The Union of Educational Institutions.

Ebel, R.L. 1972. Essentials of educational measurement. (3rd. ed.) Englewood Cliffts,NJ: Prentice Hall Inc.

Fernandes, H.J. X. 1984. Evaluation of educational program. Jakarta: National Education Planning, Evaluating and Curriculum Development.

Feldt, L.S. and Brennan, R.L. 1989. "Reliability", Educational measurement, edited by Robert L Linn. New York: Macmillan Publishing Company.

Gwet, K.L.2012. Handbook of inter-rater reliability. MD: Advanced Analytics

Lawrence M.R. 1994. Question to ask when evaluaating test. Eric digest. Artikel: ED385607. Sumber: http://www.ericfacility.net/ericdigest/ ed.385607.html tanggal 10 Februari 2003.

Moore, B., Stanly, T. 2010. Critical thinking and formative assessments. Larchmount, NY: Eye On Education, Inc

Multon, Keren D. 2012. "Interrater reliability”. Encyclopedia of research design.Ed. Neil J. Salkind. Thousand Oaks, CA: SAGE, 2010. 627 - 629. SAGE Reference online. Web. 18 July 2012

Nitko, A.J. 1996. Penilaian berkelanjutan berdasarkan kurikulum (PB2K): Kerangka, konsep, prosedur, dan kebijakan (terj. AM. Ahmad) Jakarta: Pusat Pengembangan Agribisnis.

Perpres R.I. Nomor 8 Tahun 2012 Tentang Kerangka Kualifikasi Nasional Indonesia

Permendikbud R.I. Nomor 66 Tahun 2013 Tentang Standar Penilaian

Reynolds, C.R., Livingston, R.B., dan Wilson, V. 2008. Measurement and Assessment in Education. Englewood Cliffs, NJ: Prentice-Hall,Inc. 
Saifuddin Azwar. 2013. Validitas dan reliabilitas. Ed.4. Yogyakarta: Pustaka Pelajar

Salkind, N.J. 2013. Test \& measurement for people who hate test and measurement. Los Angeles: SAGE Publications, Inc

Thomas, A. dan Thorne, G. (2007). Higher Order Thinking. Center for Development and learning. Diambil dari CDL pda tanggal 6 Agustus 2011.

Woolfolk, A.E. \& McCune, L.N. 1984. Educational Psychology for Teachers. Englewood Cliffs, NJ: Prentice Hall, Inc. 